\title{
Obituary: Patrick J. Williams
}

\author{
Timothy Baker ${ }^{1} \cdot$ Nick Oliver ${ }^{2}$
}

Received: 16 January 2019 / Accepted: 17 January 2019/Published online: 29 January 2019

(C) Springer-Verlag GmbH Germany, part of Springer Nature 2019

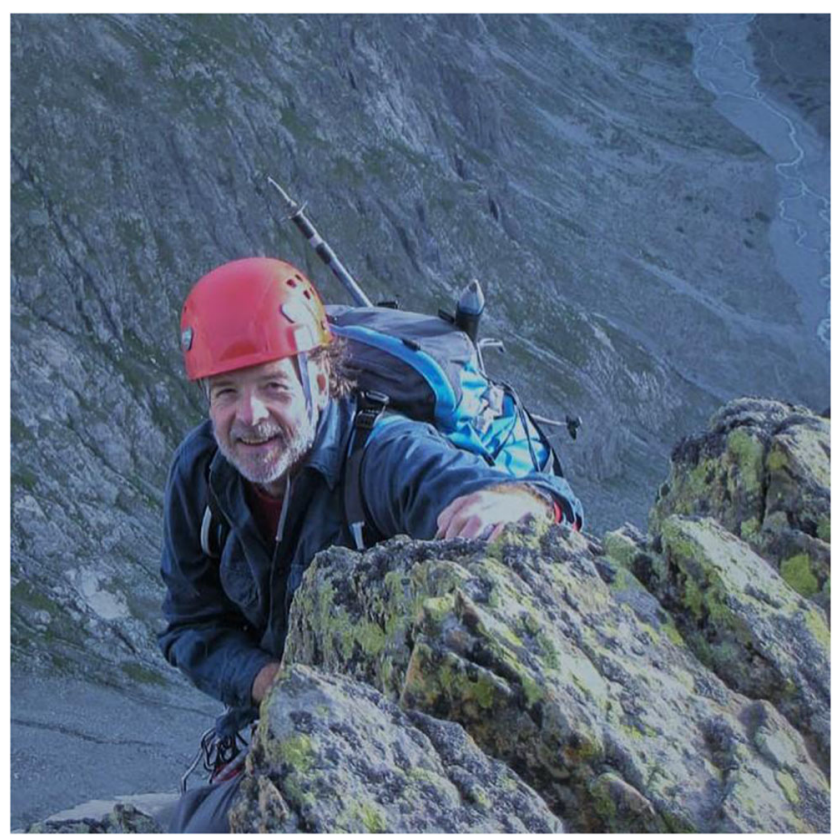

It is with great sadness that we report the passing of Pat Williams, former editor of Mineralium Deposita (2008-2012).

Patrick John Williams died July 5, 2018, at the age of 61. He peacefully passed away surrounded by friends and family on the Isle of Anglesey, UK, following a six-year battle with cancer.

Pat was born March 14th 1957 in Widnes, Cheshire, UK, and obtained a B.Sc. Geology from the University of

Editorial handling: G. Beaudoin

Timothy Baker

timb@eldoradogold.com

Eldorado Gold Corp., Vancouver, BC, Canada

2 HolcombeCoughlinOliverValenta, Townsville, Queensland, Australia
Liverpool in 1978. During the same year, he commenced his Ph.D. at the University of Southampton under the supervision of Dr. Nick Badham. His research focused on metamorphosed massive sulfide deposits in NW Spain. Following the award of his Ph.D. in 1982, he took up a lectureship position at Goldsmiths College, University of London, and during his 7-year tenure was promoted to Senior Lecturer.

In 1990, Pat moved to James Cook University in Townsville, Australia. JCU was one of the first universities in Australia to establish strong academic-mining industry collaboration through the Economic Geology Research Unit, the establishment of the Key Centre in Economic Geology, and later the Predictive Mineral Discovery CRC. Pat was instrumental in the development of mineral deposit focused research and teaching programs, particularly on the Mount Isa Inlier. He became recognized as a global expert in IOCG deposits, developed through research on this emerging deposit type in the Cloncurry district following several significant new discoveries during the nineties such as Ernest Henry, Osborne, and Eloise. With his graduate students, he also contributed to research on the newly discovered Cannington $\mathrm{Ag}-\mathrm{Pb}-\mathrm{Zn}$ deposit and other $\mathrm{Pb}-\mathrm{Zn}$ systems in the Mount Isa region. Much of this early research was presented at the Mount IsaCloncurry conference in Townsville in 1996 that Pat organized in collaboration with the growing body of Mount Isa focused economic geology research students. The meeting established a model for numerous subsequent Townsvillebased international ore deposit conferences including the SGA Conference in 2009 which Pat co-organized with Nick Oliver and Brian Rusk.

Pat's Mount Isa and IOCG research was captured in several key papers including his guest editor special issue of Economic Geology in 1998 and the landmark 100th anniversary Economic Geology volume in 2005 with a paper entitled "Iron Oxide Copper-Gold Deposits: Geology, Space-Time Distribution, and Possible Modes of Origin." He was also much valued as an academic colleague and an excellent mentor for his postgraduate students. In addition, he made a major contribution to JCU undergraduate teaching in mineralogy, 
petrology, and economic geology. His subsequent consulting career commenced in 2008 as Director of Clump Mountain Geoscience and included major mining clients such as MMG and $\mathrm{Oz}$ Minerals.

In addition to a passion for geoscience, Pat's interests included hiking and mountaineering particularly in the Munros of Scotland. His choice of undergraduate university was no coincidence due to his love of Liverpool FC. He played football with both skill and commitment in the over 35 leagues in
Townsville for more than 20 years (with a broken leg for efforts on one occasion) and represented the Townsville Has Beens right up until May this year. Pat will be missed by the economic geology community in Australia and beyond, and his many friends and family in North Queensland and the UK.

Publisher's note Springer Nature remains neutral with regard to jurisdictional claims in published maps and institutional affiliations. 